\title{
A didática do cinema nos processos de ensino-aprendizagem: teoria e práxis educativa
}

The didactics of cinema in teaching and learning

processes: theory and educational praxis

Rui Guimarães Lima*

\begin{abstract}
Alves, Luís Alberto; García García, Francisco; Alves, Pedro (Coord.) Aprender del cine: narrativa y didáctica

Madrid: Icono14 Editorial; Porto: CITCEM, 2014. 232p.
\end{abstract}

Publicada com a chancela editorial da associação científica "Icono14", na sua coleção Estudios de Narrativa, em coedição com a Unidade de Investigação CITCEM (Centro de Investigação Transdisciplinar "Cultura, Espaço e Memória”, da Faculdade de Letras da Universidade do Porto), a obra Aprender del cine: narrativa y didáctica reúne um importante conjunto de estudos académicos assinados por conceituados especialistas dos dois países ibéricos, orbitando em torno de temas como a produção e narrativa cinematográficas, a receção fílmica, a sua pragmática e o estudo da sua aplicação em contextos educacionais, consubstanciando-se num relevante labor teórico e empírico, de caráter transdisciplinar, ao delimitar o seu objeto de estudo e perspetivar ainda futuras linhas de investigação e desenvolvimento.

Deste modo, podemos dividir em três partes o livro em análise. A primeira das quais, a qual designaremos das questões introdutórias, contém, além da "Nota de abertura" deste que é considerado, por Pedro Alves, como "o primeiro resultado impresso de um projeto internacional ... que visa explorar teórica e empiricamente o potencial narrativo e fílmico no âmbito de contextos educativos" (p.11), um resumo biográfico dos nove autores que assinam os seus diversos capítulos. Na segunda parte, a obra desenvolve-se ao longo de seis capítulos nucleares, dois dos quais, nomeadamente os da autoria de Francisco García García ("El cine como ágora: saber y compartir las imágenes de un

\footnotetext{
* Doutor em Ciências da Educação. Centro de Investigação Transdisciplinar "Cultura, Espaço e Memória” (CITCEM). Faculdade de Letras da Universidade do Porto (FLUP). Porto, Portugal. rglima@letras.up.pt
} 
relato fílmico") e de Mario Rajas ("Estrategias del discurso narrativo: participación activa del espectador en el relato cinematográfico”), centrando a sua análise a nível da produção cinematográfica, da sua linguagem específica e dos seus respetivos impactos; paralelamente, o texto deste último autor, juntamente com o capítulo redigido por Pedro Alves ("Pragmática del espectador en las narrativas fílmicas"), abordam, sob um ponto de vista teórico, as problemáticas associadas à receção cinematográfica do espetador; e ainda outros três capítulos, respetivamente da autoria de Pérez García e Muñoz Ruíz (“Análisis didáctico de narrativa audiovisual"), de Cláudia Ribeiro e Luís Alberto Alves ("Uso do Cinema na didática da História"), e de Tiago Reigada ("Relato de uma experiencia didática com o Cinema") que, num prisma teórico-empírico e versando especificamente a disciplina de História, ilustram um rol de experiências de aplicação pedagógico-didática do cinema, bem como a sua origem e evolução histórica ao longo do século XX, designadamente em Portugal.

Por fim, a terceira e última parte da publicação, que apelidaremos de reflexões conclusivas, é constituída pelas "Notas conclusivas", da responsabilidade de João Teixeira Lopes, proporcionando-nos um peculiar enfoque tendo por base a sociologia da arte, bem como pela "Contextualização histórica e prospetiva do projeto" que, integrado num programa de investigação internacional e considerando o cinema como um poderoso recurso ou ferramenta didática, incide sobre as potencialidades e as orientações relativas à sua utilização pedagógica em contexto de sala de aula, projeto científico esse que foi catapultado e tem vindo a ser dinamizado e implementado, em Portugal, pela Unidade de Investigação CITCEM, em parceria com a supracitada Associação Científica "Icono14", com sede na capital espanhola.

Efetivamente, culminando na sua forma impressa um projeto já iniciado em 2012, então com a designação de "Cinema, Didática e Cultura”, esta publicação, ainda de acordo com Pedro Alves, um dos coordenadores desta edição, surge na sequência lógica da dinamização e produção de "vários seminários de reflexão ... artigos científicos e teses de doutoramento centradas no objeto de estudo" (Alves, 2015, p.11). Em boa verdade, e sob um ponto de vista estritamente teórico, as referências bibliográficas elencadas no labor dos investigadores que participaram na produção deste livro acaba por constituir-se numa compilação extremamente atual do "estado da arte" neste campo de pesquisa, patenteando-se, numa apropriação da terminologia da "sétima arte", como um autêntico "plano de pormenor" para a comunidade científica, para o público 
especializado ou para todos aqueles que nutrem particular interesse nas temáticas nele aportadas.

Portanto, e numa constante ao longo dos diversos capítulos da obra, os autores procedem à articulação teórico-prática do cinema como recurso didático, quer seja com base numa problematização de cariz mais teórico (Cf. García; Ruíz), quer seja através do debate histórico (Cf. Ribeiro; Alves) ou ainda da discussão com um cunho mais pragmático (por exemplo, através da descrição sumária de um estudo de caso, no âmbito da disciplina de História; Cf. Reigada).

Por conseguinte, a pesquisa e a investigação científica de variáveis que se correlacionem com a introdução, exploração e maximização da "sétima arte" em contextos educativos e enquanto recurso pedagógico-didático é, nos nossos dias, tanto mais premente quanto mais abundante é a proliferação da produção cinematográfica. Em última análise, e como muito apropriadamente assinala outro dos coordenadores editoriais desta publicação, Luís Alberto Alves (2015, p.227),

O desiderato é transformar o distanciamento que essa gramática e vocabulário próprios podem criar, num processo de aproximação gradual, sistemático, informado, didático, possível quando os 'especialistas' estão conscientes da realidade e quando o simples passatempo se pode transformar num verdadeiro espaço de aprendizagem.

Por fim, digno de registo é ainda o facto de esta publicação representar inequivocamente um marco na "luta contra o estigma da marginalização das investigações no domínio das ciências humanas e sociais, constituindo, por isso, uma prova evidente do 'espirito de sobrevivência' da vontade de investigar, contra os muros de natureza financeira que são erguidos de forma (in) esperada" (Alves, 2015, p.13).

Concluindo, e como brilhantemente sintetiza Pereira (2015, p.450),

Fragmentos de investigações doutorais em conclusão ou repositórios de longas experiências de investigação académica sobre o tema, consoante os respectivos autores, cada artigo constitui um campo denso de problematização que, como em qualquer programa científico, desdobra cada resposta que encontra num novo nicho de perguntas e questões que se ergue.

Resenha recebida em 10 de abril de 2016. Aprovada em 20 de maio de 2016. 